Keywords: histopathological regression; oesophagogastric adenocarcinomas; neoadjuvant treated; surgery; prognostic factors; multivariate analysis; signet ring cell cancer; localisation

\title{
Prognostic value of histopathological regression in 850 neoadjuvantly treated oesophagogastric adenocarcinomas
}

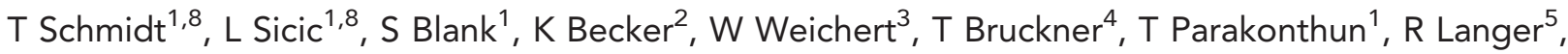 \\ M W Büchler ${ }^{1}$, J-R Siewert ${ }^{6}, F$ Lordick $^{7,8}$ and $\mathrm{K} \mathrm{Ott}^{\star, 1,8}$
}

${ }^{1}$ Department of General, Visceral and Transplantation Surgery, University of Heidelberg, Im Neuenheimer Feld 110, 69120 Heidelberg, Germany; ${ }^{2}$ Department of Pathology, Technische Universitaet Muenchen, 81675 Munich, Germany; ${ }^{3}$ Department of Pathology, University of Heidelberg, 69120 Heidelberg, Germany; ${ }^{4}$ Institute of Medical Biometry and Informatics (IMBI), University of Heidelberg, 69120 Heidelberg, Germany; ${ }^{5}$ Department of Pathology, University of Bern, 3010 Bern, Switzerland; ${ }^{6}$ Directorate, University of Freiburg, 79095 Freiburg, Germany and 'University Cancer Center Leipzig (UCCL), University of Leipzig, 04103 Leipzig, Germany

Background: Recently, histopathological tumour regression, prevalence of signet ring cells, and localisation were reported as prognostic factors in neoadjuvantly treated oesophagogastric (junctional and gastric) cancer. This exploratory retrospective study analyses independent prognostic factors within a large patient cohort after preoperative chemotherapy including clinical and histopathological factors.

Methods: In all, 850 patients presenting with oesophagogastric cancer staged cT3/4 Nany cM0/x were treated with neoadjuvant chemotherapy followed by resection in two academic centres. Patient data were documented in a prospective database and retrospectively analysed.

Results: Of all factors prognostic on univariate analysis, only clinical response, complications, ypTNM stage, and R category were independently prognostic $(P<0.01)$ on multivariate analysis. Tumour localisation and signet ring cells were independently prognostic only when investigator-dependent clinical response evaluation was excluded from the multivariate model. Histopathological tumour regression correlates with tumour grading, Laurén classification, clinical response, ypT, ypN, and $\mathrm{R}$ categories but was not identified as an independent prognostic factor. Within RO-resected patients only surgical complications and ypTNM stage were independent prognostic factors.

Conclusions: Only established prognostic factors like ypTNM stage, R category, and complications were identified as independent prognostic factors in resected patients after neoadjuvant chemotherapy. In contrast, histopathological tumour regression was not found as an independent prognostic marker.

Perioperative chemotherapy for locally advanced oesophagogastric cancer is a recommended standard of care in Europe (Cunningham et al, 2006, 2008; Ychou et al, 2011; Lutz et al, 2012). For adenocarcinomas of the oesophagogastric junction (AEG), neoadjuvant chemoradiotherapy has been suggested to further improve response rates and prognosis (Stahl et al, 2009; Burmeister et al, 2011; Sjoquist et al, 2011; van Hagen et al, 2012), although the 5 -year survival gain reported in the CROSS study is in the same range as in the MAGIC (Cunningham et al, 2006) and FFCD (Ychou et al, 2011) perioperative chemotherapy studies. However,

\footnotetext{
*Correspondence: Professor Dr K Ott; E-mail: katja.ott@med.uni-heidelberg.de
}

${ }^{8}$ These authors contributed equally to this work.

Received 13 October 2013; revised 21 January 2014; accepted 27 January 2014; published online 25 February 2014 
the histopathological complete response rates of the CROSS study and the results in the surgery alone arm were excellent and similar rates were reached in only a few other randomised controlled multicentre studies (Hulscher et al, 2002).

The evaluation of prognostic factors within neoadjuvantly treated patients was mainly performed retrospectively within phase II studies with limited patient numbers (Lowy et al, 1999; Becker et al, 2003; Mansour et al, 2007; Fujitani et al, 2012; Lorenzen et al, 2012; Koh et al, 2013). The reliability of these reports is limited by the relatively small sample size of most of the studies, and by heterogeneity with regard to the patient cohorts, to neoadjuvant treatment, response evaluation and histopathological regression (HPR) scoring systems. The factors included in the respective multivariate analysis strongly affect the study results and are difficult to compare. Often, ypT category, $\mathrm{ypN}$ category, Laurén classification, tumour localisation, tumour differentiation, perineural or vascular invasion, and response were selected by Cox regression (Lowy et al, 1999; Becker et al, 2003; Mansour et al, 2007; Fujitani et al, 2012; Lorenzen et al, 2012; Koh et al, 2013).

Larger series mostly focussed on single prognostic factors of interest. Special attention was recently paid to three factors: localisation (Kunz et al, 2012; Lorenzen et al, 2012; Reim et al, 2012), HPR (Langer et al, 2009; Becker et al, 2011), and signet ring cell cancer (SRC) (Messager et al, 2011; Kunz et al, 2012; Taghavi et al, 2012). However, most of these factors were not even used for stratification within clinical trials, because they were judged to be too weak or too difficult to assess on a standardised basis to enable stratification to be performed.

Response to neoadjuvant treatment is an important clinical readout for tumour biology and was first described by Lowy et al. for gastric adenocarcinomas (Lowy et al, 1999). The focus of this study is the histopathological tumour regression after chemotherapy, which was found to be an independent prognostic factor in a large series with gastric cancer (GC) (Becker et al, 2011). Despite being considered as the gold standard for response evaluation, histopathological response is still not clearly defined and several competing scoring systems associated with prognosis exist (Kurihara and Aiko, 2001; Mansour et al, 2007; Becker et al, 2011). Most often, patients with $<10 \%$ residual tumour are classified as responder (Schneider et al, 2008; Becker et al, 2011; Lorenzen et al, 2012). But it needs to be noted that about $30 \%$ of patients with an obvious HPR of the primary tumour still die due to recurrence (Fields et al, 2011; Ott et al, 2013). HPR assessment is not free of bias and it depends on the experience of the respective pathologist and the processing of the resection specimens. Given these limitations, the significance of HPR as an independent prognostic factor remains unclear. The value of HPR as a prognostic factor needs to be analysed alongside clinical response, as clinical response was shown to be prognostic by our group and others (Lowy et al, 1999; Ott et al, 2003; Weber et al, 2003), but was deemed to be investigator dependent by other groups (Schneider et al, 2008).

The aim of our retrospective exploratory study from two academic centres was the analysis of independent prognostic factors with special emphasis on influence of HPR, but also including other factors like clinical response, signet ring cells, and localisation within a large series of resected oesophagogastric adenocarcinomas treated with preoperative chemotherapy.

\section{PATIENTS AND METHODS}

This retrospective exploratory study includes 850 (of a total of 952) patients $(n=675$ Department of Surgery, Klinikum Rechts der Isar, TU München and $n=175$ Department of General, Visceral and Transplantation Surgery, University of Heidelberg) with histologically proven locally advanced stage $\left(\mathrm{cT}_{3 / 4}\right.$ and $\left.\mathrm{cN}_{\text {any }}\right)$ AEG and GC after neoadjuvant chemotherapy followed by surgical resection (Figure 1).

Preoperative staging, neoadjuvant chemotherapy, and surgical therapy. The staging procedures before initiation of chemotherapy included endoscopy and computed tomography of the chest and the abdomen. Staging was repeated before resection to determine clinical response and to exclude distant metastases. The neoadjuvant chemotherapy was mostly platinum based. Patients underwent established chemotherapy regimens, including combinations of platinum (cis- or oxaliplatin) with 5-fluorouracil (or capecitabine) either or not combined with anthracyclines (epirubicin) or taxanes (paclitaxel or docetaxel) (Lim et al, 2003; Bader et al, 2008; Blank et al, 2013) (Supplementary Table S1).

Surgery. Resection was according to tumour localisation and local standards (Bader et al, 2008; Ott et al, 2008, 2009; Blank et al, 2013; Sisic et al, 2013). Tumours of the oesophagogastric junction were treated by transhiatal extended gastrectomy, abdomino-thoracic oesophagectomy, or transhiatal oesophagectomy. Gastric cancers of the middle and distal gastric third were treated with total or subtotal gastrectomy. All surgical approaches included an abdominal D2 lymphadenectomy.

Histopathological workup and response assessment. The histopathological workup was classified and staged according to the recommendations by the Union for International Cancer Control (UICC), 7th edition (UICC, 2010). Histopathological response was graded according to Becker et al (2003, 2011). Grade 1 response indicates complete or subtotal regression with 1a complete regression and $1 \mathrm{~b}<10 \%$ residual tumour tissue. Grade 2 response indicated partial tumour regression with $10-50 \%$ residual tumour and grade 3 minimal or no tumour regression ( $>50 \%$ residual tumour).

Clinical response evaluation. Clinical response was defined by the interdisciplinary tumour board based on a combination of

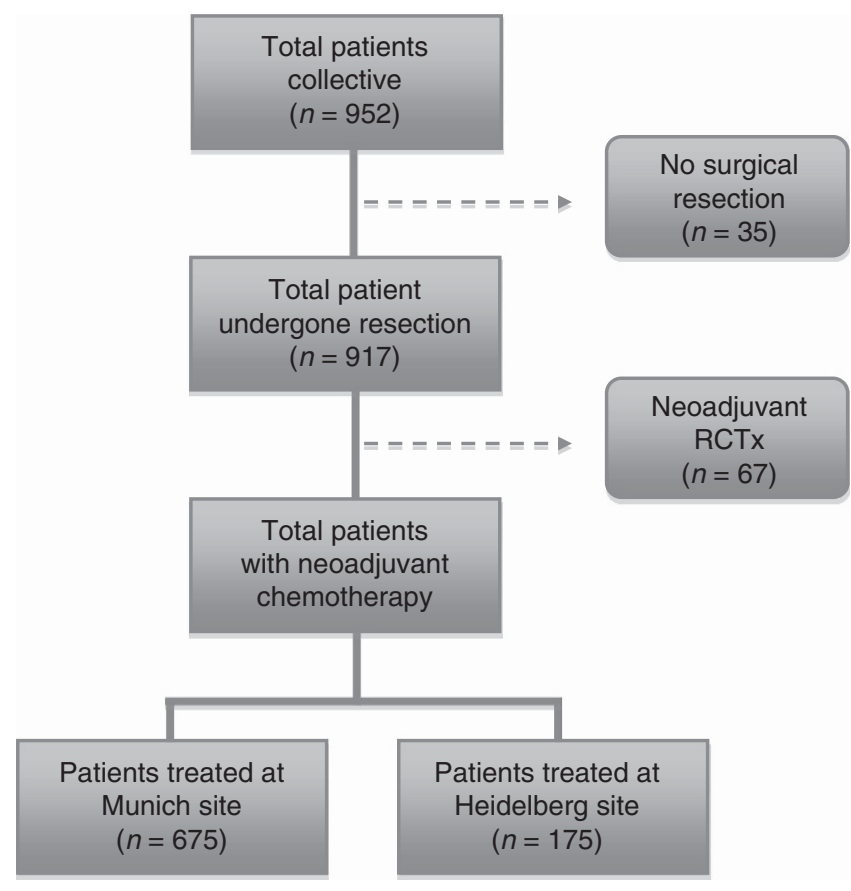

Figure 1. Patient collective. Flowchart describing the composition of the patient collective included in this study. 
endoscopy and CT scan after neoadjuvant treatment before resection without the knowledge of the histopathological workup. Responders were defined with at least a partial response (PR) to both endoscopy ( $<75 \%$ residual tumour) and CT scan (decrease of $>50 \%$ in the wall diameter) (Ott et al, 2003).

Patient follow-up. The patients were followed up routinely on an outpatient basis according to a standard protocol with visits q3 month in the first year, q6 month in the second and third year and yearly afterwards until the end of the fifth year. Patients who did not participate in this programme were contacted by telephone to obtain follow-up data.

Statistical analysis. Overall survival was evaluated in months from time of diagnosis until death or until the most recent followup using the Kaplan-Meier method. Differences in the survival curves were evaluated by log-rank test for significance. Quantitative values are expressed as mean \pm standard deviation, median, and range, and categorical values with absolute and relative frequencies (count and percent). $\chi^{2}$ test was used for comparison of frequencies, and Spearman correlation coefficients were calculated to quantify bivariate correlation. Stepwise Cox proportional hazard regression was performed as multivariate analysis with forward and backward regression models. A $P$-value of smaller than 0.05 was considered as statistically significant and all statistical tests were conducted two-sided. IBM SPSS Version 20 (Ehningen, Germany) was used for analysis.

\section{RESULTS}

Patients. The patients had a median age of 57.5 years (range 17-80) and were predominantly male $(n=687(79.8 \%))$. The tumour was localised at the oesophagogastric junction (junctional cancer) in 610 and in the stomach in 240 patients. Further patients' characteristics are presented in detail in Table 1. Clinical response was evaluated in 824 of the 850 patients. In all, 28.6\% (236) were classified as responder (Table 2). The surgical procedures and postoperative complications are also listed in Table 2. Chemotherapy-associated tumour regression was evaluated according to the tumour regression system of Becker. In all, 215 tumours (25.2\%) showed a histopathological response of grade $1 \mathrm{a}(5.6 \%)$ or $1 \mathrm{~b}(19.6 \%)$, whereas the remainder showed minor or no response (Table 2).

The median survival was 37.1 months (95\% CI: $31.2-43.0$ months). The 30 -day mortality rate was $3.2 \%$ and the in-hospital mortality rate $7.9 \%$. Analysing the data according to the time point of diagnosis, no significant survival differences were observed within the different time intervals (1: 1987-12/1995; 2: 01/199612/2000; 3: 01/2001-12/2005; and 4: 01/2006-12/2010) (Supplementary Figure S1). The distribution of the surgical procedures remained similar over the study period, with the only difference that in earlier time points transhiatal oesophageal resection was favoured over abdomino-thoracic oesophageal resection (Supplementary Table S2A). The number of resected/analysed lymph nodes was higher at earlier time points (Supplementary Table S2B)

Prognostic factors. Kaplan-Meier curves analysed by log-rank test revealed tumour grading, Laurén classification, SRC (according to WHO definition), clinical response, total complications, surgical complications, resection status (R0 vs R1/2), ypTNM stage and HPR (grade $1 \mathrm{a} / \mathrm{b}$ vs grade $2 / 3$ ) and detailed HPR (all grades separately) (total and surgical complications $P=0.005$, all others $P<0.001)$ as prognostic factors by univariate analysis in all included patients. On the other side, completion of the full planned chemotherapy regimen, site of treatment (Munich vs Heidelberg), or chemotherapy regimen (anthracycline-containing vs taxanecontaining $v s$ non-anthracycline-non-taxane-containing) were not found to be a prognostic factor.

\begin{tabular}{|c|c|}
\hline & $n(\%)$ \\
\hline \multicolumn{2}{|l|}{ Gender } \\
\hline $\begin{array}{l}\text { Male } \\
\text { Female }\end{array}$ & $\begin{array}{l}678(79.8) \\
172(20.2)\end{array}$ \\
\hline \multicolumn{2}{|l|}{ Localisation } \\
\hline $\begin{array}{l}\text { Oesophagus } \\
\text { AEG I } \\
\text { AEG II } \\
\text { AEG III } \\
\text { Gastric } \\
\text { Gastric body } \\
\text { Gastric antrum } \\
\text { Total gastric carcinoma }\end{array}$ & $\begin{array}{c}610(71.8) \\
241(28.4) \\
254(29.9) \\
115(13.5) \\
240(28.2) \\
94(11.1) \\
94(11.1) \\
52(6.1)\end{array}$ \\
\hline \multicolumn{2}{|l|}{ Grading $^{a}$} \\
\hline $\begin{array}{l}\mathrm{G} 1 / 2 \\
\mathrm{G} 3 / 4\end{array}$ & $\begin{array}{l}217(25.9) \\
621(74.1)\end{array}$ \\
\hline \multicolumn{2}{|l|}{ Laurén classification $^{a}$} \\
\hline $\begin{array}{l}\text { Intestinal type } \\
\text { Non-intestinal type }\end{array}$ & $\begin{array}{l}436(52.3) \\
397(47.7)\end{array}$ \\
\hline \multicolumn{2}{|c|}{ Signet ring cell cancer ${ }^{a}$} \\
\hline $\begin{array}{l}\text { Yes } \\
\text { No }\end{array}$ & $\begin{array}{l}221(30.0) \\
516(70.0)\end{array}$ \\
\hline
\end{tabular}

Histopathological regression as a prognostic factor. Histopathological regression grade was found to be strongly associated with survival. Patients with tumour regression grade $1(1 \mathrm{a}+1 \mathrm{~b})$ had a median survival of 92.2 months (CI: median survival not reached). For patients without regression, median survival was 27.9 months (95\% CI: $24.2-31.6$ months) (Figure 2A) $(P<0.001)$. Histopathological regression based on the four groups (grades 1a, 1b, 2, and 3) did also significantly discriminate the patients' prognosis $(P<0.001)$ (Figure 2B). Histopathological response was significantly associated with the preoperative grading $(P=0.001)$ and Laurén classification of the tumour $(P=0.002)$. Histopathological response was correlated with clinical response $(P<0.001)$, but not with discontinuation of chemotherapy. The postoperative parameters of ypT, ypN, and R categories were associated with HPR $(P<0.001)$, whereas the M category not (Supplementary Table S3). A more detailed analysis showed that in patients with a histopathological response of the primary tumour, lymph-node metastases are relatively frequent in the pathological specimens. In all, $20.9 \%$ (10 out of 48 ) of the patients with regression grade 1a and $41.6 \%$ (67 out of 161 ) (Table 3 ) with grade $1 \mathrm{~b}$ had lymph-node metastases as well as distant metastases in $8.3 \%$ (4 out of 48 ) vs $21.1 \%$ (34 out of 161) (Supplementary Table S4). In all, 55.7\% (93 out of 161) of the responders with grade $1 \mathrm{~b}$ had an advanced $\mathrm{T}$ category with yT3 and yT4 and $13.8 \%$ (23 out of 167) of those had tumour infiltration of the surgical resection margins (R1/R2) (Supplementary Table S4).

Clinical response, localisation, and signet ring cell carcinoma. The analysis of clinical response showed a significantly better prognosis for clinical responders $v s$ non-responders (Figure $3 \mathrm{~A}$ ) $(P<0.001)$. Subgroup analysis showed a significant survival 


\begin{tabular}{|c|c|}
\hline & $n(\%)$ \\
\hline \multicolumn{2}{|l|}{ Clinical response } \\
\hline $\begin{array}{l}\text { Responder } \\
\text { Non-responder } \\
\text { Minor response } \\
\text { No change } \\
\text { Progressive disease }\end{array}$ & $\begin{array}{c}236(28.6) \\
590(71.4) \\
298(36.1) \\
267(32.3) \\
25(3.0)\end{array}$ \\
\hline \multicolumn{2}{|l|}{ Surgical procedure } \\
\hline $\begin{array}{l}\text { Abdomino-thoracic oesophageal resection } \\
\text { Transmediastinal oesophageal resection } \\
\text { Oesophago-gastrectomy } \\
\text { Transhiatal extended gastrectomy } \\
\text { Total gastrectomy } \\
\text { Subtotal gastrectomy } \\
\text { Others }\end{array}$ & $\begin{aligned} 201 & (23.6) \\
88 & (10.4) \\
9 & (1.1) \\
295 & (34.7) \\
208 & (24.5) \\
35 & (4.1) \\
14 & (1.6)\end{aligned}$ \\
\hline \multicolumn{2}{|l|}{ Complications } \\
\hline $\begin{array}{l}\text { Yes } \\
\text { Surgical } \\
\text { Medical }\end{array}$ & $\begin{array}{l}352(41.5) \\
135(15.9) \\
282(33.2)\end{array}$ \\
\hline \multicolumn{2}{|l|}{ ypT category } \\
\hline $\begin{array}{l}\text { ypT0 } \\
\text { ypT1 } \\
\text { ypT2 } \\
\text { ypT3 } \\
\text { ypT4 }\end{array}$ & $\begin{array}{c}48(5.6) \\
62(7.3) \\
101(11.9) \\
505(59.4) \\
134(15.8)\end{array}$ \\
\hline \multicolumn{2}{|l|}{ ypN category } \\
\hline $\begin{array}{l}\text { ypN0 } \\
\text { ypN1 } \\
\text { ypN2 } \\
\text { ypN3 }\end{array}$ & $\begin{array}{l}314(37.3) \\
147(17.5) \\
146(17.3) \\
235(27.9)\end{array}$ \\
\hline \multicolumn{2}{|l|}{ M category } \\
\hline $\begin{array}{l}\text { M0 } \\
\text { M1 }\end{array}$ & $\begin{array}{l}674(79.3) \\
176(20.7)\end{array}$ \\
\hline \multicolumn{2}{|l|}{ R category } \\
\hline $\begin{array}{l}\text { R0 } \\
\text { R1 } \\
\text { R2 }\end{array}$ & $\begin{array}{c}637(74.9) \\
177(20.8) \\
36(4.2)\end{array}$ \\
\hline \multicolumn{2}{|l|}{ HPR } \\
\hline $\begin{array}{l}\text { Grade 1a } \\
\text { Grade 1b } \\
\text { Grade } 2 \\
\text { Grade } 3\end{array}$ & $\begin{array}{c}48(5.6) \\
167(19.6) \\
208(24.5) \\
427(50.2)\end{array}$ \\
\hline $\begin{array}{l}\text { Abbreviations: HPR = histopathological regression; UICC } \\
\text { TNM classification according to UICC } 7 \text { th edition. }\end{array}$ & mational Cance \\
\hline
\end{tabular}

difference for patients with a PR (median survival: not reached), minor response (MR) (median survival: 29.1 months, 95\% CI: 22.1-36.1 months), no change (NC) (median survival: 27.1 months, 95\% CI: 23.0-32.2 months), and progressive disease (PD) (median survival: 10.5 months, 95\% CI: 9.1-11.9 months) (Figure 3B).

Also the tumour localisation was found to be a significant prognostic marker. Patients with a carcinoma involving the entire stomach had a worse prognosis, whereas all other localisations had a similar survival (Figure 3C).

When analysing the patients for signet ring cell carcinoma vs non-signet ring cell carcinoma, it was found that patients with signet ring cell carcinoma (median survival: 26.7 months, 95\% CI: 22.1-31.4 months) had a significantly worse survival than nonsignet ring cell type carcinoma patients (median survival: 46.6 months, 95\% CI: 37.9-55.2 months) (Figure 3D, $P<0.001$ ).

Analysing only the 637 R0-resected patients by log-rank tests revealed comparable results for prognostic factors with significant differences for tumour location, tumour grading, Laurén classification, SRC, clinical response, total complications, surgical complications, ypTNM, and HPR (grade $1 \mathrm{a} / \mathrm{b}$ vs grade $2 / 3$ ).

Independent prognostic factors. Multivariate analysis with Cox forward and backward regression revealed clinical response, total complications, and $\mathrm{ypT}$ and $\mathrm{ypN}$ categories as independent prognostic factors. $\mathrm{M}$ and $\mathrm{R}$ categories were independent prognostic factors in Cox forward regression, but not confirmed in backward regression. HPR was not confirmed as an independent prognostic factor neither included as parameter responder $v s$ non-responder nor with the detailed regression classification (Table 4A). In the next step clinical response was deleted, because it is not a generally accepted prognostic factor within all working groups, because it is judged to be investigator dependent. Without clinical response Cox regression revealed tumour location, SRC, total complications, and ypTNM and R categories as independent prognostic markers in forward and backward Cox regression, again not HPR (Table 4B). Despite tumour localisation was statistically significant, the survival curves are crossing (Figure 3C). Therefore, this parameter was deleted from further analysis. Then in multivariate analysis, total complications, and ypTNM and R categories remained as independent prognostic factors (Table 4C).

By multivariate Cox regression analysis (forward and backward regression), surgical complications and ypTNM categories were identified as independent prognostic factors (all $P<0.005$ ) in the completely resected patients (Table $4 \mathrm{D}$ ). As expected distant metastasis (M1 status) was a prognostic factor, therefore Cox regression analysis was also performed for all patients without distant metastasis (M0) (Supplementary Table S5A) and all curatively resected patients with complete resection (R0) and without distant metastasis (M0) (Supplementary Table S5B). In these patient groups, localisation, clinical response, and ypTN categories remained as independent prognostic factors, whereas HPR was not found to be statistically significant.

\section{DISCUSSION}

This study shows that established prognostic factors like ypTNM and $\mathrm{R}$ categories, as well as complications, are independent prognostic factors in neoadjuvant treated oesophagogastric adenocarcinomas. Hence, similar factors were also revealed to be prognostically relevant for primary resected tumours. Chemotherapy-associated characteristics such as histopathological response scoring were shown to be less important. Even patients with a good response in their primary tumour often have high $\mathrm{T}$ categories and lymph-node metastases, which may be responsible for the lower relevance of the tumour regression score in multivariate analysis. Only one localisation influences outcome in our analysis: carcinomas of the entire stomach have a disastrous prognosis compared with all other localisations (Messager et al, 2011; Lorenzen et al, 2012).

Limitations in other studies are usually related to the inclusion of only a few preselected parameters. Additionally, differences in survival over the study period can be observed (Kunz et al, 2012). In general, it needs to be noted that only a few prospective randomised 


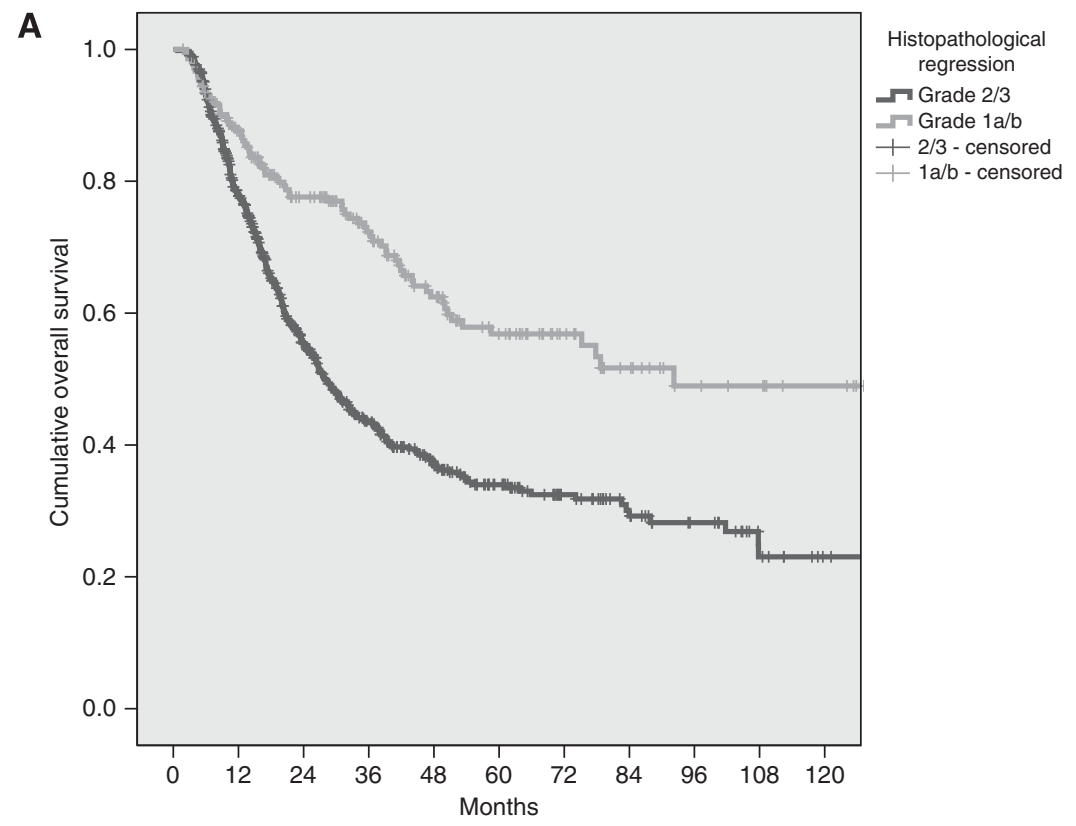

\begin{tabular}{|l|c|c|c|c|c|c|c|c|c|c|c|}
\hline & \multicolumn{10}{|c|}{ Months } \\
\hline Pts at risk & 0 & 12 & 24 & 36 & 48 & 60 & 72 & 84 & 96 & 108 & 120 \\
\hline Responder & 209 & 165 & 123 & 96 & 68 & 46 & 33 & 22 & 16 & 13 & 6 \\
\hline Non-resp. & 612 & 422 & 247 & 156 & 100 & 66 & 44 & 30 & 20 & 9 & 3 \\
\hline
\end{tabular}

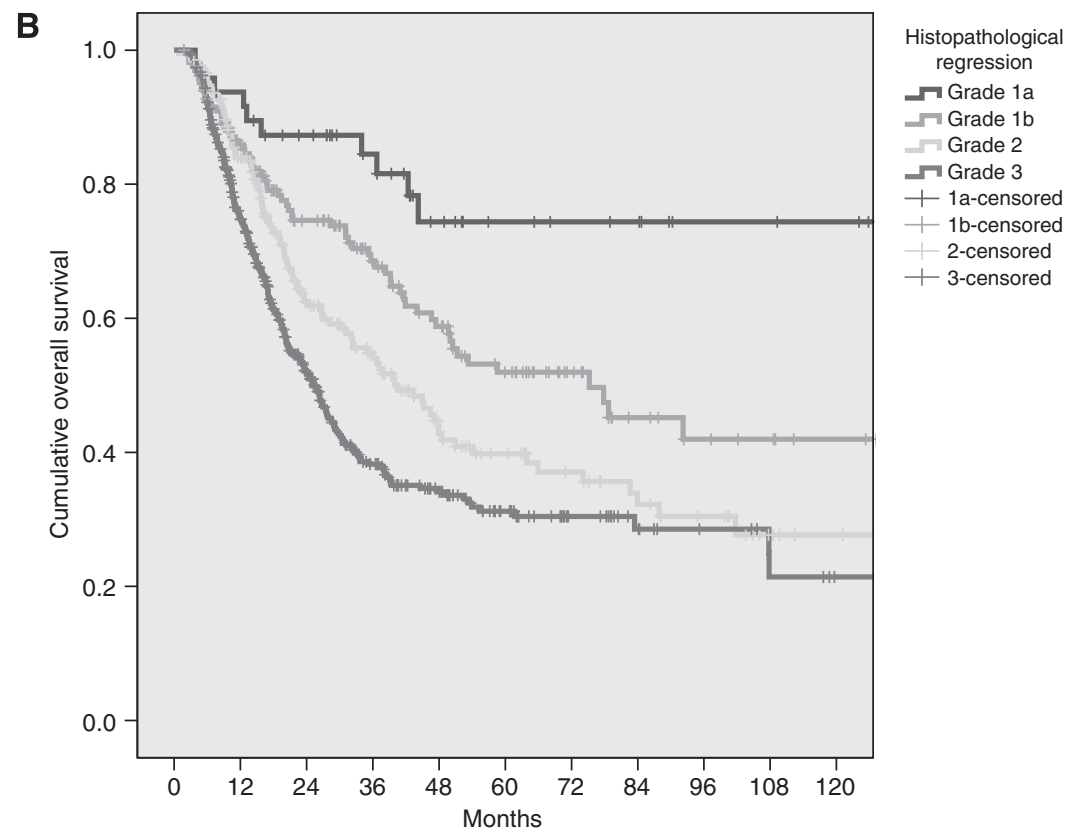

\begin{tabular}{|l|c|c|c|c|c|c|c|c|c|c|c|}
\hline & \multicolumn{10}{|c|}{ Months } \\
\hline Pts at risk & 0 & 12 & 24 & 36 & 48 & 60 & 72 & 84 & 96 & 108 & 120 \\
\hline Grade 1a & 48 & 42 & 34 & 25 & 15 & 11 & 10 & 7 & 5 & 4 & 2 \\
\hline Grade 1b & 161 & 123 & 89 & 71 & 53 & 35 & 23 & 15 & 11 & 9 & 4 \\
\hline Grade 2 & 200 & 148 & 90 & 65 & 41 & 31 & 24 & 17 & 11 & 4 & 1 \\
\hline Grade 3 & 412 & 274 & 157 & 91 & 49 & 35 & 20 & 13 & 9 & 5 & 2 \\
\hline
\end{tabular}

Figure 2. Prognostic value of the histopathological regression. Kaplan-Meier plots for overall survival of (A) histopathological regression grading grouped grade $1 \mathrm{a} / \mathrm{b}$ and group $2 / 3$ and $(\mathbf{B})$ histopathological regression by subgrades $(n=850, P<0.001)$. The tables show the number of patients at risk at the indicated time points.

phase III studies exist (Cunningham et al, 2006; Schuhmacher et al, 2010; Ychou et al, 2011) and that the evaluation of prognostic factors is not a primary objective of phase III studies. Hence, there are currently some questions that can only be answered retrospectively (Messager et al, 2011; Kunz et al, 2012), but results must be interpreted with caution and with the awareness of this limitation.
Considering these limitations, the analysis of our data is more comprehensive compared with many other published series. We included a multiplicity of factors such as Laurén classification, grading, clinical response, HPR, and SRC classification according to the WHO. In addition, the clinical information including the type and conduct of preoperative chemotherapy and intraoperative 
Table 3. Lymph-node metastasis according to histopathological regression

Histopathological regression

\begin{tabular}{|l|c|c|c|c|}
\hline $\begin{array}{l}\text { Lymph-node } \\
\text { metastasis }\end{array}$ & 1a & 1b & $\mathbf{2}$ & $\mathbf{3}$ \\
\hline Negative & $38(79.2 \%)$ & $94(58.4 \%)$ & $76(36.7 \%)$ & $106(24.9 \%)$ \\
\hline Positive & $10(20.8 \%)$ & $67(41.6 \%)$ & $131(53.3 \%)$ & $310(75.1 \%)$ \\
\hline
\end{tabular}

The table indicates the number of patients with lymph-node metastasis according to histopathological regression (HPR) as well as the percentage of patients with lymph-node metastasis for each specific HPR grade.
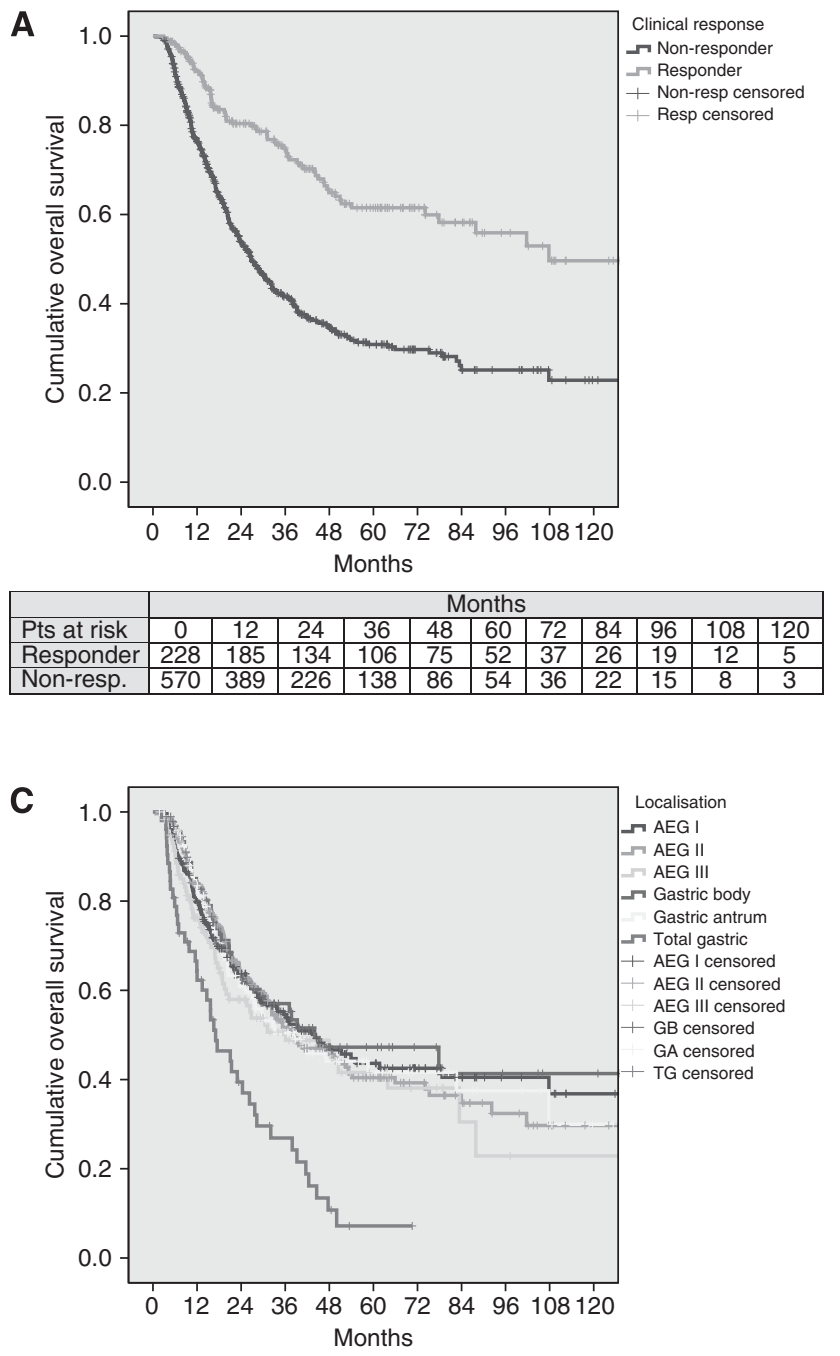

\begin{tabular}{|l|c|c|c|c|c|c|c|c|c|c|c|}
\hline & \multicolumn{10}{|c|}{ Months } \\
\hline Pts at risk & 0 & 12 & 24 & 36 & 48 & 60 & 72 & 84 & 96 & 108 & 120 \\
\hline AEG I & 237 & 168 & 105 & 71 & 49 & 35 & 24 & 16 & 12 & 8 & 3 \\
\hline AEG II & 247 & 186 & 122 & 84 & 60 & 38 & 27 & 17 & 11 & 5 & 2 \\
\hline AEG III & 107 & 67 & 39 & 25 & 18 & 12 & 7 & 4 & 3 & 2 & 1 \\
\hline G. body & 89 & 66 & 41 & 29 & 18 & 12 & 9 & 7 & 5 & 4 & 2 \\
\hline G. antr. & 92 & 72 & 48 & 33 & 22 & 15 & 11 & 8 & 6 & 3 & 1 \\
\hline Tot. g. & 50 & 29 & 16 & 10 & 3 & 1 & 0 & 0 & 0 & 0 & 0 \\
\hline
\end{tabular}

and postoperative complications was available. Some other interesting information, like initial pretherapeutic cTNM (Messager et al, 2011; Reim et al, 2012), was not completely recorded in our database and therefore was not included (Blank et al, 2012). Furthermore, no detailed information on pretherapeutic performance status or nutritional status was available (Messager et al, 2011), but all of our patients who were selected for multimodal treatment had to have a Karnofsky performance status of $>80$. Despite prospective meticulous documentation of many factors, some prognostically relevant factors like lymphangiosis (von Rahden et al, 2005), perineural or vascular invasion (Mansour et al, 2007), or tumour regression within the lymph nodes (Bollschweiler et al, 2011) were only recorded for small subgroups and were not included in our analysis. As overall survival did not
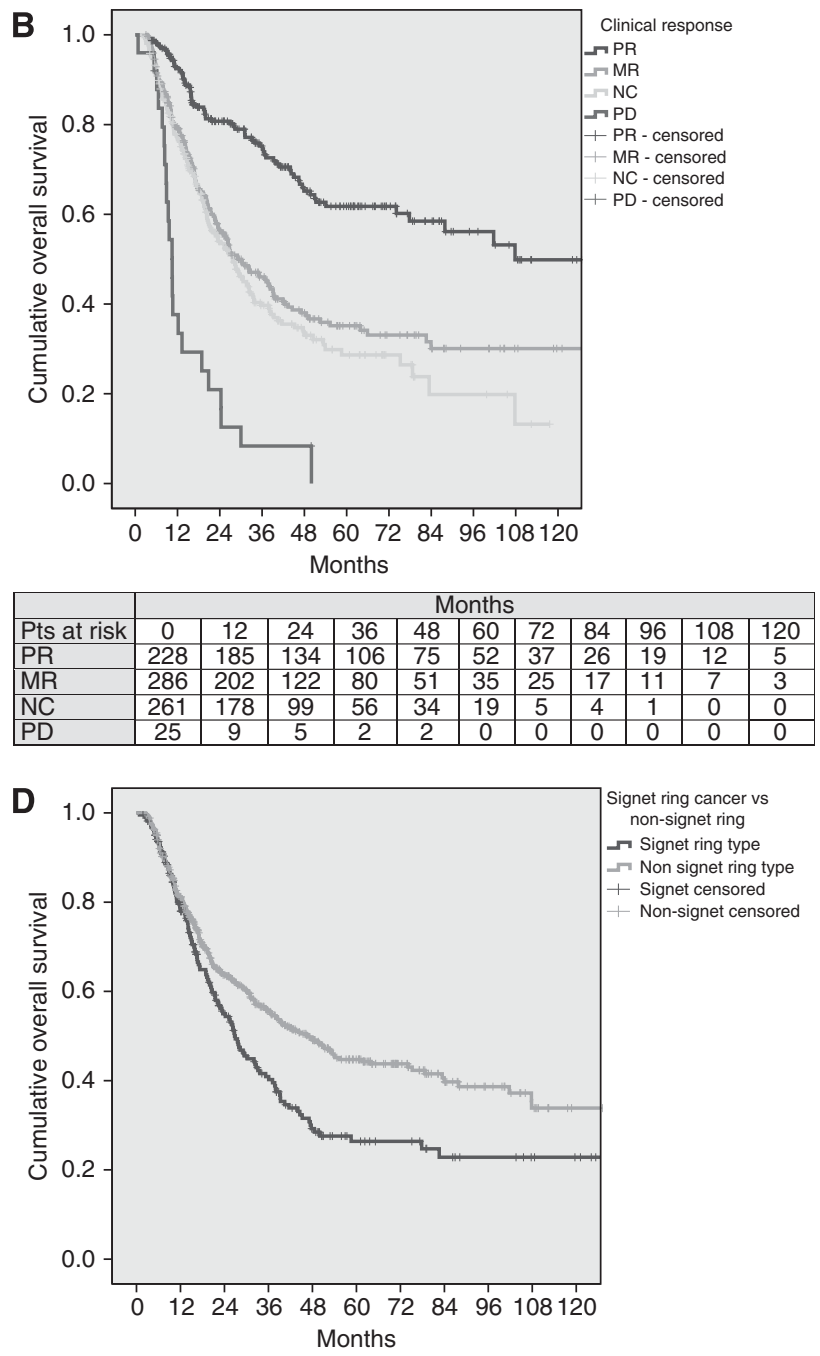

\begin{tabular}{|l|c|c|c|c|c|c|c|c|c|c|c|}
\hline & \multicolumn{10}{|c|}{ Months } \\
\hline Pts at risk & 0 & 12 & 24 & 36 & 48 & 60 & 72 & 84 & 96 & 108 & 120 \\
\hline Signet & 210 & 143 & 86 & 57 & 31 & 20 & 16 & 11 & 8 & 5 & 2 \\
\hline Non-signet & 504 & 368 & 142 & 176 & 125 & 84 & 57 & 38 & 27 & 16 & 6 \\
\hline
\end{tabular}

Figure 3. Clinical response, localisation, and signet ring cell carcinoma as prognostic factors. Kaplan-Meier plots for overall survival of (A) clinical response grouped by responders and non-responders, (B) clinical response of partial response (PR), minor response (MR), no change (NC), progressive disease (PD) and (C) according to tumour localisation of the primary tumour. (A-C, $n=850, P<0.001)$ (D) according to tumour type, signet ring cell cancer vs non-signet ring cell cancer $(n=737, P<0.001)$. The tables show the number of patients at risk at the indicated time points. 
Table 4. Significant prognostic factors in multivariate analyses

$$
\begin{array}{l|l|l}
P \text {-value } & \text { RR } & 95 \% \mathrm{Cl}
\end{array}
$$

(A) (included: localisation, grading, Laurén classification, signet ring cell cancer, clinical response, complications, surgical complications, ypTNM, R status, and histopathological regression)

\begin{tabular}{|l|r|r|l|}
\hline Clinical response $^{\mathrm{a}}$ & 0.004 & 1.53 & $1.14-2.05$ \\
\hline Complications $^{\mathrm{a}}$ & 0.001 & 0.70 & $0.57-0.87$ \\
\hline ypT category $^{\mathrm{a}}$ & 0.002 & & \\
\hline ypT0 & 0.009 & 0.31 & $0.13-0.75$ \\
ypT1 & 0.039 & 0.51 & $0.27-0.97$ \\
ypT2 & $<0.001$ & 0.42 & $0.26-0.68$ \\
ypT3 & 0.140 & 0.81 & $0.61-1.07$ \\
\hline ypN category & & \\
\hline ypN0 & $<0.001$ & & \\
ypN1 & $<0.001$ & 0.45 & $0.33-0.63$ \\
ypN2 & 0.010 & 0.65 & $0.47-0.90$ \\
M category & 0.003 & 0.66 & $0.48-0.68$ \\
\hline R category & $<0.001$ & 0.55 & $0.42-0.73$ \\
\hline R0 & 0.014 & & \\
R1 & 0.018 & 0.55 & $0.34-0.91$ \\
& 0.240 & 0.75 & $0.47-1.21$ \\
\hline
\end{tabular}

(B) (clinical response excluded) (included: localisation, grading, Laurén classification, signet ring cell cancer, complications, surgical complications, ypTNM, R status, and histopathological regression)

\begin{tabular}{|l|r|l|l|}
\hline Localisation $^{\text {a }}$ & 0.006 & & \\
\hline Signet cell type cancer $^{\mathrm{a}}$ & 0.033 & 1.32 & $1.02-1.70$ \\
\hline Complications $^{\mathrm{a}}$ & 0.004 & 0.73 & $0.58-0.90$ \\
\hline ypT category $^{\mathrm{a}}$ & $<0.001$ & & \\
\hline ypT0 & $<0.001$ & 0.19 & $0.08-0.47$ \\
ypT1 & 0.006 & 0.39 & $0.20-0.76$ \\
ypT2 & $<0.001$ & 0.38 & $0.23-0.64$ \\
ypT3 & 0.075 & 0.73 & $0.52-1.03$ \\
\hline ypN category & $<0.001$ & & \\
\hline ypN0 & $<0.001$ & 0.40 & $0.29-0.56$ \\
ypN1 & 0.001 & 0.57 & $0.41-0.79$ \\
ypN2 & $<0.001$ & 0.60 & $0.45-0.80$ \\
\hline M category & \\
\hline R category & $<0.001$ & 0.53 & $0.40-0.70$ \\
\hline R0 & 0.009 & & \\
R1 & 0.004 & 0.48 & $0.29-0.79$ \\
\hline & 0.041 & 0.60 & $0.37-0.98$ \\
\hline
\end{tabular}

(C) (clinical response + localisation excluded) (included: grading, Laurén classification, signet ring cell cancer, complications, surgical complications, ypTNM, R status, and histopathological regression)

\begin{tabular}{|c|c|c|c|}
\hline Complications $^{a}$ & $<0.001$ & 0.69 & $0.56-0.85$ \\
\hline yрT category ${ }^{a}$ & $<0.001$ & & \\
\hline урт0 & 0.001 & 0.23 & $0.10-0.55$ \\
\hline урТ1 & 0.008 & 0.42 & $0.23-0.80$ \\
\hline урТ2 & $<0.001$ & 0.40 & $0.28-0.72$ \\
\hline урТ3 & 0.198 & 0.84 & $0.64-1.1$ \\
\hline ypN category ${ }^{a}$ & $<0.001$ & & \\
\hline ypNO & $<0.001$ & 0.43 & $0.32-0.59$ \\
\hline ypN1 & 0.003 & 0.61 & $0.44-0.85$ \\
\hline ypN2 & 0.002 & 0.63 & $0.47-0.84$ \\
\hline M category ${ }^{a}$ & $<0.001$ & 0.55 & $0.42-0.72$ \\
\hline R category ${ }^{a}$ & 0.006 & & \\
\hline RO & 0.011 & 0.53 & $0.33-0.86$ \\
\hline R1 & 0.212 & 0.74 & $0.46-1.19$ \\
\hline
\end{tabular}

Table 4. (Continued)

$$
\begin{array}{l|l|l|}
P \text {-value } & \text { RR } & 95 \% \mathrm{Cl}
\end{array}
$$

(D) (RO completely resected patients) (included: grading, Laurén classification, signet ring cell cancer, clinical response, complications, surgical complications, ypTNM, and

\begin{tabular}{|c|c|c|c|}
\hline Surgical complications ${ }^{a}$ & 0.004 & 0.68 & $0.52-0.89$ \\
\hline ypT category ${ }^{a}$ & $<0.001$ & & \\
\hline урT0 & 0.002 & 0.25 & $0.10-0.61$ \\
\hline урT1 & 0.011 & 0.40 & $0.19-0.81$ \\
\hline урT2 & $<0.001$ & 0.36 & $0.21-0.63$ \\
\hline урT3 & 0.318 & 0.922 & $0.56-1.21$ \\
\hline ypN category ${ }^{a}$ & $<0.001$ & & \\
\hline ypNO & $<0.001$ & 0.39 & $0.27-0.57$ \\
\hline ypN1 & 0.006 & 0.58 & $0.39-0.85$ \\
\hline ypN2 & 0.006 & 0.59 & $0.41-0.86$ \\
\hline $\mathrm{M}$ category $^{\mathrm{a}}$ & $<0.001$ & 0.47 & $0.33-0.67$ \\
\hline \multicolumn{4}{|c|}{$\begin{array}{l}\text { Abbreviations: } \mathrm{Cl}=\text { confidence interval; } \mathrm{RR}=\text { relative risk. } \\
{ }^{\mathrm{a}} \text { Confirmation by Cox backward regression analysis. } \\
\text { Results of Cox forward regression analysis. }\end{array}$} \\
\hline
\end{tabular}
histopathological regression)

change significantly over the study period, inclusion of all patients over this long time period remains justified.

This study provides important insights into the outcome of neoadjuvantly treated patients. As a fundamental finding, TNM classification seems to be the strongest prognostic factor in neoadjuvantly treated patients, despite being based on the data from primary resected patients (Gertler et al, 2011; Reim et al, 2013). The prognostic relevance of complications is known in oesophagogastric adenocarcinoma (Ott et al, 2009; Messager et al, 2011), and was confirmed in our study. Interestingly, for both groups, the resected and completely (R0) resected patients, the same prognostic factors were revealed to be significant. Therapyassociated variables, for example, discontinuation of chemotherapy or the type of cytotoxic drug combinations applied, were not statistically relevant or meaningful because of small subgroups and crossing survival curves.

The inclusion of different localisations of adenocarcinomas as stratification criterion in studies is a matter of debate because, according to centres and standards, the associated treatment strategies might differ significantly. Since our study is focussed on patients with chemotherapy only, all treated adenocarcinomas were included according to the MAGIC and FFCD study results (Cunningham et al, 2006; Ychou et al, 2011). There is an ongoing discussion regarding whether in AEG I, or even in AEG II and III, preoperative chemoradiotherapy should be performed (Sjoquist et al, 2011; van Hagen et al, 2012). In our centres, we mostly used chemotherapy alone due to the reduced immunosuppression after chemotherapy compared with radiochemotherapy (Heidecke et al, 2002) and due to the good local resectability of adenocarcinomas in most cases (Siewert and Ott, 2007). Whether the significantly higher rates of complete histopathological responses after chemoradiotherapy compared with chemotherapy are also translated into an improved survival remains unclear so far (Vallbohmer et al, 2010; Fields et al, 2011; Ott et al, 2013), as only limited prospectively controlled randomised data addressing this issue exist (Stahl et al, 2009; Burmeister et al, 2011). In contrast to primary resected AEG (Siewert et al, 2001), in this study all localisations have a similar prognosis with only cancers of the entire stomach having a significantly worse prognosis. This supports our combined analysis of adenocarcinomas in the upper GI after chemotherapy.

The most remarkable and debatable finding of our retrospective study was the lack of independent prognostic relevance of the 
tumour regression score. It was previously shown that about $30 \%$ of patients classified as histopathological responders die due to recurrence, mostly occurring as distant metastases (Fields et al, 2011; Ott et al, 2013). Here, we found that a relevant percentage of patients with $<10 \%$ residual tumour have advanced tumour categories and/or lymph-node metastases. Although the findings from the largest series for GC support tumour regression as an independent prognostic factor (Becker et al, 2011), there are also other studies in the literature that contradict this finding and thus support our data (Mansour et al, 2007; Fujitani et al, 2012). We integrated all pre- and postoperative relevant parameters, including clinical and histopathological information, as Cox regression analysis is dependent on the chosen factors. None of the performed analyses revealed tumour regression as an independent prognostic factor. Interestingly, clinical response was an independent prognostic factor, but it was excluded from further analysis, because it is judged to be investigator dependent.

Despite the lack of significance in multivariate analysis, HPR remains an important piece of information after preoperative chemotherapy, because it represents an in vivo testing of the chemosensitivity of the tumour and may serve as a stratification criterion for tailored postoperative treatment in future studies. Its clinical relevance must be interpreted with caution, as there are several classification systems available in the literature (Becker et al, 2003, 2011; Fujitani et al, 2012), with classification of responders varying from a complete $\mathrm{HPR}$ to $<50 \%$ residual tumour (Becker et al, 2003; Mansour et al, 2007; Fujitani et al, 2012). A homogenisation of scoring systems, a standardisation resection specimen processing, and a consensus definition of a histopathological response after chemotherapy are strongly warranted to make study results comparable in the future.

In conclusion, in neoadjuvantly treated oesophagogastric adenocarcinomas, only established factors such as ypTNM categories and total complications, and no chemotherapy related factors, are revealed as independent prognostic factors in our series. Specifically, HPR was not an independent prognostic factor. Advanced tumour categories and lymph-node metastases in $>40 \%$ of patients with $<10 \%$ residual tumour might be one reason. Therefore, since no generally accepted scoring systems exist, HPR should be interpreted with caution and might be used for postoperative treatment decisions only in combination with the established prognostic factors.

\section{ACKNOWLEDGEMENTS}

We thank Dr Emmalene Bartlett for her valuable comments and help with the editing of this manuscript.

\section{REFERENCES}

Bader FG, Lordick F, Fink U, Becker K, Hofler H, Busch R, Siewert JR, Ott K (2008) Paclitaxel in the neoadjuvant treatment for adeno carcinoma of the distal esophagus (AEG I). A comparison of two phase II trials with long-term follow-up. Onkologie 31: 366-372.

Becker K, Langer R, Reim D, Novotny A, Meyer zum Buschenfelde C, Engel J, Friess H, Hofler H (2011) Significance of histopathological tumor regression after neoadjuvant chemotherapy in gastric adenocarcinomas: a summary of 480 cases. Ann Surg 253: 934-939.

Becker K, Mueller JD, Schulmacher C, Ott K, Fink U, Busch R, Bottcher K, Siewert JR, Hofler H (2003) Histomorphology and grading of regression in gastric carcinoma treated with neoadjuvant chemotherapy. Cancer $\mathbf{9 8}$ : $1521-1530$.

Blank S, Blaker H, Schaible A, Lordick F, Grenacher L, Buechler M, Ott K (2012) Impact of pretherapeutic routine clinical staging for the individualization of treatment in gastric cancer patients. Langenbecks Arch Surg 397: 45-55.
Blank S, Stange A, Sisic L, Roth W, Grenacher L, Sterzing F, Burian M, Jager D, Buchler M, Ott K (2013) Preoperative therapy of esophagogastric cancer: the problem of nonresponding patients. Langenbecks Arch Surg 398: 211-220.

Bollschweiler E, Holscher AH, Metzger R, Besch S, Monig SP, Baldus SE, Drebber U (2011) Prognostic significance of a new grading system of lymph node morphology after neoadjuvant radiochemotherapy for esophageal cancer. Ann Thorac Surg 92: 2020-2027.

Burmeister BH, Thomas JM, Burmeister EA, Walpole ET, Harvey JA, Thomson DB, Barbour AP, Gotley DC, Smithers BM (2011) Is concurrent radiation therapy required in patients receiving preoperative chemotherapy for adenocarcinoma of the oesophagus? A randomised phase II trial. Eur J Cancer 47: 354-360.

Cunningham D, Allum WH, Stenning SP, Thompson JN, Van de Velde CJ, Nicolson M, Scarffe JH, Lofts FJ, Falk SJ, Iveson TJ, Smith DB, Langley RE, Verma M, Weeden S, Chua YJ, Participants MT (2006) Perioperative chemotherapy versus surgery alone for resectable gastroesophageal cancer. $N$ Engl J Med 355: 11-20.

Cunningham D, Starling N, Rao S, Iveson T, Nicolson M, Coxon F, Middleton G, Daniel F, Oates J, Norman AR (2008) Capecitabine and oxaliplatin for advanced esophagogastric cancer. N Engl J Med 358: 36-46.

Fields RC, Strong VE, Gonen M, Goodman KA, Rizk NP, Kelsen DP, Ilson DH, Tang LH, Brennan MF, Coit DG, Shah MA (2011) Recurrence and survival after pathologic complete response to preoperative therapy followed by surgery for gastric or gastrooesophageal adenocarcinoma. Br J Cancer 104: 1840-1847.

Fujitani K, Mano M, Hirao M, Kodama Y, Tsujinaka T (2012) Posttherapy nodal status, not graded histologic response, predicts survival after neoadjuvant chemotherapy for advanced gastric cancer. Ann Surg Oncol 19: 1936-1943.

Gertler R, Stein HJ, Langer R, Nettelmann M, Schuster T, Hoefler H, Siewert JR, Feith M (2011) Long-term outcome of 2920 patients with cancers of the esophagus and esophagogastric junction: evaluation of the New Union Internationale Contre le Cancer/American Joint Cancer Committee staging system. Ann Surg 253: 689-698.

Heidecke CD, Weighardt H, Feith M, Fink U, Zimmermann F, Stein HJ, Siewert JR, Holzmann B (2002) Neoadjuvant treatment of esophageal cancer: Immunosuppression following combined radiochemotherapy. Surgery 132: 495-501.

Hulscher JB, van Sandick JW, de Boer AG, Wijnhoven BP, Tijssen JG, Fockens P, Stalmeier PF, ten Kate FJ, van Dekken H, Obertop H, Tilanus HW, van Lanschot JJ (2002) Extended transthoracic resection compared with limited transhiatal resection for adenocarcinoma of the esophagus. New Engl J Med 347: 1662-1669.

Koh YW, Park YS, Ryu MH, Ryoo BY, Park HJ, Yook JH, Kim BS, Kang YK (2013) Postoperative nodal status and diffuse-type histology are independent prognostic factors in resectable advanced gastric carcinomas after preoperative chemotherapy. Am J Surg Pathol 37: 1022-1029.

Kunz PL, Gubens M, Fisher GA, Ford JM, Lichtensztajn DY, Clarke CA (2012) Long-term survivors of gastric cancer: a California populationbased study. J Clin Oncol 30: 3507-3515.

Kurihara M, Aiko T (2001) The new Japanese classification of gastric carcinoma: revised explanation of 'response assessment of chemotherapy and radiotherapy for gastric carcinoma'. Gastric Cancer 4: 9-13.

Langer R, Ott K, Feith M, Lordick F, Siewert JR, Becker K (2009) Prognostic significance of histopathological tumor regression after neoadjuvant chemotherapy in esophageal adenocarcinomas. Mod Pathol 22: $1555-1563$.

Lim JTW, Truong PT, Berthelet E, Pai H, Joe H, Wai E, Larsson S, Kader HA, Weinerman B, Wilson K, Olivotto IA (2003) Endoscopic response predicts for survival and organ preservation after primary chemoradiotherapy for esophageal cancer. Int J Radiat Oncol Biol Phys 57: 1328-1335.

Lorenzen S, Blank S, Lordick F, Siewert JR, Ott K (2012) Prediction of response and prognosis by a score including only pretherapeutic parameters in 410 neoadjuvant treated gastric cancer patients. Ann Surg Oncol 19: 2119-2127.

Lowy AM, Mansfield PF, Leach SD, Pazdur R, Dumas P, Ajani JA (1999) Response to neoadjuvant chemotherapy best predicts survival after curative resection of gastric cancer. Ann Surg 229: 303-308.

Lutz MP, Zalcberg JR, Ducreux M, Ajani JA, Allum W, Aust D, Bang YJ, Cascinu S, Holscher A, Jankowski J, Jansen EP, Kisslich R, Lordick F, Mariette C, Moehler M, Oyama T, Roth A, Rueschoff J, Ruhstaller T, 
Seruca R, Stahl M, Sterzing F, van Cutsem E, van der Gaast A van Lanschot J, Ychou M, Otto F (2012) Highlights of the EORTC St. Gallen International Expert Consensus on the primary therapy of gastric gastroesophageal and oesophageal cancer - differential treatment strategies for subtypes of early gastroesophageal cancer. Eur J Cancer 48: 2941-2953.

Mansour JC, Tang L, Shah M, Bentrem D, Klimstra DS, Gonen M, Kelsen DP, Brennan MF, Coit DG (2007) Does graded histologic response after neoadjuvant chemotherapy predict survival for completely resected gastric cancer? Ann Surg Oncol 14: 3412-3418.

Messager M, Lefevre JH, Pichot-Delahaye V, Souadka A, Piessen G, Mariette C (2011) The impact of perioperative chemotherapy on survival in patients with gastric signet ring cell adenocarcinoma: a multicenter comparative study. Ann Surg 254: 684-693discussion 693.

Ott K, Bader FG, Lordick F, Feith M, Bartels H, Siewert JR (2009) Surgical factors influence the outcome after Ivor-Lewis esophagectomy with intrathoracic anastomosis for adenocarcinoma of the esophagogastric junction: a consecutive series of 240 patients at an experienced center. Ann Surg Oncol 16: 1017-1025.

Ott K, Blank S, Becker K, Langer R, Weichert W, Roth W, Sisic L, Stange A, Jager D, Buchler M, Siewert JR, Lordick F (2013) Factors predicting prognosis and recurrence in patients with esophago-gastric adenocarcinoma and histopathological response with less than $10 \%$ residual tumor. Langenbecks Arch Surg 398: 239-249.

Ott K, Lordick F, Herrmann K, Krause BJ, Schuhmacher C, Siewert JR (2008) The new credo: induction chemotherapy in locally advanced gastric cancer: consequences for surgical strategies. Gastric Cancer 11: 1-9.

Ott K, Sendler A, Becker K, Dittler HJ, Helmberger H, Busch R, Kollmannsberger C, Siewert JR, Fink U (2003) Neoadjuvant chemotherapy with cisplatin, 5-FU, and leucovorin (PLF) in locally advanced gastric cancer: a prospective phase II study. Gastric Cancer 6: 159-167.

Reim D, Gertler R, Novotny A, Becker K, zum Buschenfelde CM, Ebert M, Dobritz M, Langer R, Hoefler H, Friess H, Schumacher C (2012) Adenocarcinomas of the esophagogastric junction are more likely to respond to preoperative chemotherapy than distal gastric cancer. Ann Surg Oncol 19: 2108-2118.

Reim D, Loos M, Vogl F, Novotny A, Schuster T, Langer R, Becker K, Hofler H, Siveke J, Bassermann F, Friess H, Schuhmacher C (2013) Prognostic implications of the seventh edition of the international union against cancer classification for patients with gastric cancer: the Western experience of patients treated in a single-center European institution. J Clin Oncol 31: 263-271.

Schneider PM, Metzger R, Schaefer H, Baumgarten F, Vallbohmer D, Brabender J, Wolfgarten E, Bollschweiler E, Baldus SE, Dienes HP, Hoelscher AH (2008) Response evaluation by endoscopy, rebiopsy, and endoscopic ultrasound does not accurately predict histopathologic regression after neoadjuvant chemoradiation for esophageal cancer. Ann Surg 248: 902-908.

Schuhmacher C, Gretschel S, Lordick F, Reichardt P, Hohenberger W, Eisenberger CF, Haag C, Mauer ME, Hasan B, Welch J, Ott K, Hoelscher A, Schneider PM, Bechstein W, Wilke H, Lutz MP, Nordlinger B, Van Cutsem E, Siewert JR, Schlag PM (2010) Neoadjuvant chemotherapy compared with surgery alone for locally advanced cancer of the stomach and cardia: European Organisation for Research and Treatment of Cancer randomized trial 40954. J Clin Oncol 28: 5210-5218.

Siewert JR, Ott K (2007) Are squamous and adenocarcinomas of the esophagus the same disease? Semin Radiat Oncol 17: 38-44.
Siewert JR, Stein HJ, Feith M, Bruecher BL, Bartels H, Fink U (2001) Histologic tumor type is an independent prognostic parameter in esophageal cancer: lessons from more than 1,000 consecutive resections at a single center in the Western world. Ann Surg 234: 360-367; discussion 368-9.

Sisic L, Blank S, Weichert W, Jager D, Springfeld C, Hochreiter M, Buchler M, Ott K (2013) Prognostic impact of lymph node involvement and the extent of lymphadenectomy (LAD) in adenocarcinoma of the esophagogastric junction (AEG). Langenbecks Arch Surg.

Sjoquist KM, Burmeister BH, Smithers BM, Zalcberg JR, Simes RJ, Barbour A, Gebski V (2011) Survival after neoadjuvant chemotherapy or chemoradiotherapy for resectable oesophageal carcinoma: an updated meta-analysis. Lancet Oncol 12: 681-692.

Stahl M, Walz MK, Stuschke M, Lehmann N, Meyer HJ, Riera-Knorrenschild J, Langer P, Engenhart-Cabillic R, Bitzer M, Konigsrainer A, Budach W, Wilke H (2009) Phase III comparison of preoperative chemotherapy compared with chemoradiotherapy in patients with locally advanced adenocarcinoma of the esophagogastric junction. J Clin Oncol 27: 851-856.

Taghavi S, Jayarajan SN, Davey A, Willis AI (2012) Prognostic significance of signet ring gastric cancer. J Clin Oncol 30: 3493-3498.

UICC (2010) TNM Classification of Malignant Tumours. 7th edn. WCW-L: New York, NY.

Vallbohmer D, Holscher AH, DeMeester S, DeMeester T, Salo J, Peters J, Lerut T, Swisher SG, Schroder W, Bollschweiler E, Hofstetter W (2010) A multicenter study of survival after neoadjuvant radiotherapy/ chemotherapy and esophagectomy for ypT0N0M0R0 esophageal cancer. Ann Surg 252: 744-749.

van Hagen P, Hulshof MC, van Lanschot JJ, Steyerberg EW, van Berge Henegouwen MI, Wijnhoven BP, Richel DJ, Nieuwenhuijzen GA, Hospers GA, Bonenkamp JJ, Cuesta MA, Blaisse RJ, Busch OR, ten Kate FJ, Creemers GJ, Punt CJ, Plukker JT, Verheul HM, Spillenaar Bilgen EJ, van Dekken H, van der Sangen MJ, Rozema T, Biermann K, Beukema JC, Piet AH, van Rij CM, Reinders JG, Tilanus HW, van der Gaast A (2012) Preoperative chemoradiotherapy for esophageal or junctional cancer. $N$ Engl J Med 366: 2074-2084.

von Rahden BH, Stein HJ, Feith M, Becker K, Siewert JR (2005) Lymphatic vessel invasion as a prognostic factor in patients with primary resected adenocarcinomas of the esophagogastric junction. J Clin Oncol 23: 874-879.

Weber WA, Petersen V, Schmidt B, Tyndale-Hines L, Link T, Peschel C, Schwaiger M (2003) Positron emission tomography in non-small-cell lung cancer: prediction of response to chemotherapy by quantitative assessment of glucose use. J Clin Oncol 21: 2651-2657.

Ychou M, Boige V, Pignon JP, Conroy T, Bouche O, Lebreton G, Ducourtieux M, Bedenne L, Fabre JM, Saint-Aubert B, Geneve J, Lasser P, Rougier P (2011) Perioperative chemotherapy compared with surgery alone for resectable gastroesophageal adenocarcinoma: an FNCLCC and FFCD multicenter phase III trial. J Clin Oncol 29: 1715-1721.

This work is published under the standard license to publish agreement. After 12 months the work will become freely available and the license terms will switch to a Creative Commons AttributionNonCommercial-Share Alike 3.0 Unported License.

Supplementary Information accompanies this paper on British Journal of Cancer website (http://www.nature.com/bjc) 